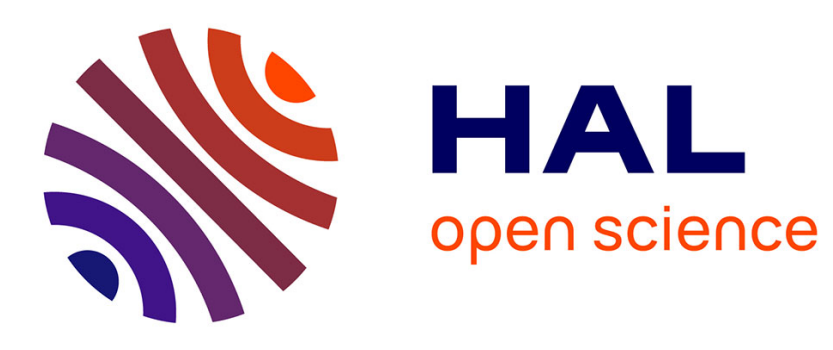

\title{
Recent advances in electrochemical meso- and $\beta$-functionalization of porphyrins and electrografting of diazonium porphyrins
}

\author{
Abdou K.D. Dimé, Asmae Bousfiha, Charles H. Devillers
}

\section{To cite this version:}

Abdou K.D. Dimé, Asmae Bousfiha, Charles H. Devillers. Recent advances in electrochemical mesoand $\beta$-functionalization of porphyrins and electrografting of diazonium porphyrins. Current Opinion in Electrochemistry, 2020, 24, pp.69-78. 10.1016/j.coelec.2020.07.004 . hal-03419604

\author{
HAL Id: hal-03419604 \\ https://hal.science/hal-03419604
}

Submitted on 8 Nov 2021

HAL is a multi-disciplinary open access archive for the deposit and dissemination of scientific research documents, whether they are published or not. The documents may come from teaching and research institutions in France or abroad, or from public or private research centers.
L'archive ouverte pluridisciplinaire HAL, est destinée au dépôt et à la diffusion de documents scientifiques de niveau recherche, publiés ou non, émanant des établissements d'enseignement et de recherche français ou étrangers, des laboratoires publics ou privés. 


\title{
Recent advances in electrochemical meso and $\beta$-functionalization of porphyrins and electrografting of diazonium-porphyrins
}

\author{
Abdou K. D. Dimé, ${ }^{a}$ Asmae Bousfiha ${ }^{b}$ and Charles H. Devillers ${ }^{b *}$ \\ ${ }^{a}$ Département de Chimie, UFR SATIC, Université Alioune Diop de Bambey, Diourbel, BP 30, \\ Sénégal. \\ ${ }^{b}$ Institut de Chimie Moléculaire de l'Université de Bourgogne UMR6302, CNRS, Univ. \\ Bourgogne Franche-Comté, 9 avenue Alain Savary, 21000 Dijon, France. E-mail: \\ charles.devillers@u-bourgogne.fr.
}

\begin{abstract}
Recent studies on electrochemical meso and $\beta$-functionalization of porphyrins and electrografting of diazonium-porphyrin are presented. First the electrochemical oxidative C-C coupling between porphyrins will be presented followed by the inter- and intramolecular meso and $\beta$-substitutions of porphyrins. Then the latest results on diazonium-porphyrin electrografting will be reviewed.
\end{abstract}

\section{Keyword}

Organic electrosynthesis; Porphyrin; Anodic nucleophilic substitution; Electropolymerization; Diazonium-porphyrin electrografting.

\section{Introduction}

Porphyrins are ubiquitous in the Nature (heme, chlorophyll) and their physico-chemical properties (UV-Vis, emission, redox...) make them particularly attractive in numerous fields. Their chemical synthesis and more particularly their functionalization in $\beta$ or meso-position(s) are often difficult to handle. An interesting green alternative to common chemical transformations consists in the electrochemical oxidation of the porphyrin ring. Thus, the electrophilic porphyrin cation radical can react with itself leading to polymers or can be substituted by one or several nucleophiles depending on the experimental conditions. In 2011 [1], 2014 [2] and 2016 [3], three book chapters from Ruhlman and co-workers adressed these topics with the description of the electrosynthesis of multisubstituted porphyrins as well as 
porphyrin electro(co)polymerization. Contributing to the impressive and exciting renaissance of organic electrosynthesis in the past few years [4-7], this short review presents the last advances on the direct electrochemical meso and $\beta$-functionalization of the porphyrin ring. Moreover, as not reported before, the electrografting of diazonium-porphyrins will be presented.

\section{Electrochemical oxidative $\mathrm{C}-\mathrm{C}$ coupling between porphyrin units}

\subsection{Dimerization and oligomerization of porphyrins}

In 2012, Devillers, Lucas and co-workers revisited the pionneer work of the Osuka's group $[8,9]$ with the study of the electrochemical dimerization of the 10-phenyl-5,15-di- $p$ tolylporphyrin $\mathrm{Zn}(\mathrm{II})$ complex (Scheme 1A) [10]. The best yield (93\%) of meso,meso dimer was obtained when the monomer was oxidized to its first oxidation potential in a non-divided cell, in DMF, in presence of 2,6-lutidine. Two years later the same group studied the analogous nickel(II) complex which gave very different results (Scheme 1A) [11]. In particular the C-C coupling occurred preferentially in the meso, $\beta$ positions affordind the singly- and doubly-linked dimer. This regioselectivity agrees well with previous results from Osuka and co-workers [9].

\subsection{Meso-meso electropolymerization of porphine}

In 2010, Devillers, Lucas and coll. reported the first detailed electrochemical characterization of magnesium(II) porphine (MgP), the totally unsubstituted porphyrin [12-14]. Electrolysis of $\mathrm{MgP}$ at its first oxidation potential led to the formation of the meso-meso dimer, trimer, tetramer and pentamer. Pursuing their research on the oxidative reactivity of $\mathrm{MgP}$, Vorotyntsev, Devillers and co-workers reported the first example of meso-meso electropolymerization of porphyrin with $\mathrm{MgP}$ (Scheme 1B) [15]. The porphine-based polymer was deposited on the electrode surface either by multiscan voltammetry or at applied potential. When the backward potential or the applied potential was low $\left(<0.40 \mathrm{~V}\right.$ vs $\left.\mathrm{Ag} / \mathrm{Ag}^{+}\right)$, a semiconducting material was obtained (pMgP-I), where the MgP unit was kept intact inside the polymer with the probable formation of only one single meso-meso bond between each 


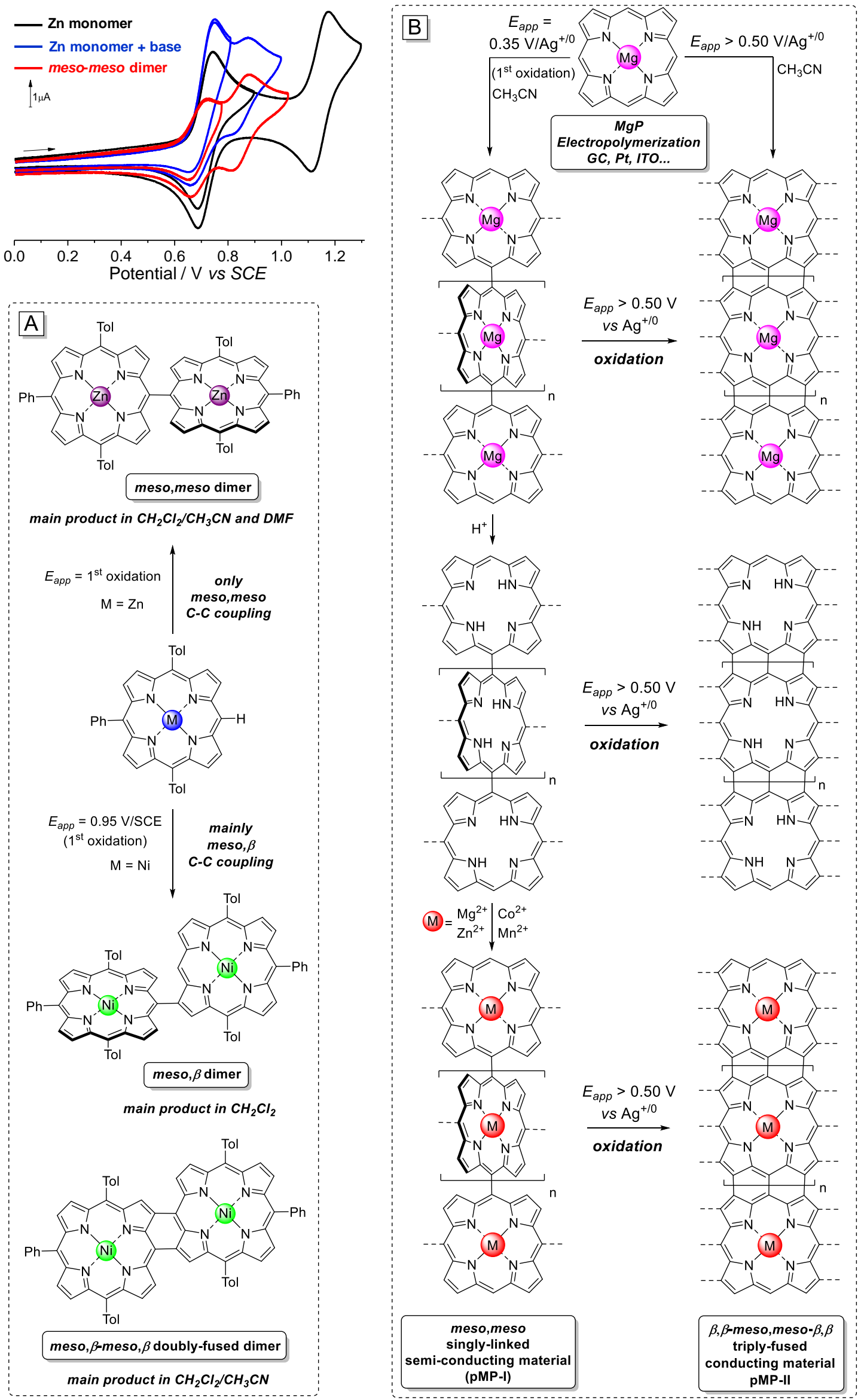

Scheme 1. Electrochemical oxidative $\mathrm{C}-\mathrm{C}$ coupling between tri-meso-arylporphyrins (A, $[10,11])$ and $\mathrm{Mg}(\mathrm{II})$ porphine (B, $[12,13,15-23])$. 
monomer unit. For higher potential $(>0.50 \mathrm{~V}) \mathrm{pMgP}-\mathrm{I}$ was transformed into another type of polymer, pMgP-II, which was electroactive in the whole available potential range [16]. Considering the different pMgP-II characterizations, it was assumed that the oxidation of $\mathrm{pMgP}-\mathrm{I}$ at potential beyond $0.50 \mathrm{~V}$ leads to the formation of two additional $\beta, \beta$ bonds between porphyrin units ( $\beta$, $\beta$-meso-meso- $\beta, \beta$ triply-fused-like polymer [24-26]) leading to a graphenelike totally planar, conjugated and conducting material.

A strong acceleration of the pMgP-I electropolymerization rate was observed upon addition of 2,6-lutidine ( $\geq 1$ eq. $v s \mathrm{MgP}$ ) [17]. The efficiency of the deposit was increased by more than a factor of two while the redox, electric conductivity and spectral properties remained unchanged.

Later, Konev, Lizgina and co-workers published a comparative electropolymerization study focused on $\mathrm{MgP}$ and 5,15-bis-(4-methoxyphenyl)porphyrin $\mathrm{Mg}(\mathrm{II})$ (MgMPP) [18]. The electrochemical behavior of MgMPP was quite similar to MgP but the polymerization rate and efficiency were much lower due to the fact that only two free meso positions are available for polymerization.

Magnesium(II) was efficiently removed from the porphine unit inside pMgP-I by addition of acids, leading to the free base porphine polymer [19]. Metallation of the free base form ( $\left.\mathrm{pH}_{2} \mathrm{P}-\mathrm{I}\right)$ was (electro)chemically performed with $\mathrm{Zn}$ (II) [19], Co(II) [20-22] and $\mathrm{Mn}$ (II) [22]. The first applications of these promising metalated materials concerned sulphite detection [23] and $\mathrm{O}_{2}$ reduction reaction [22].

\section{Electrochemical functionalization of porphyrins with nucleophiles}

\subsection{Electrochemical functionalization with nucleophile(s) at the $\beta$-position}

Several early examples of electrochemical $\beta$-functionalization have been published before 2012 [27-34]. More recently, inspired by Yoshida and coll. [35], a new pathway towards the synthesis of amino-porphyrins was developped by Devillers and co-workers [36]. Thus $5,10,15,20$-tetraphenylporphyrin $\left(\mathrm{H}_{2} \mathrm{TPP}\right)$ was oxidized in presence of a pyridine excess $(100$ 
eq.) leading to the $\beta$-pyridiniumporphyrin (Scheme 2A). Then the nucleophilic attack of an excess of piperidine on the $\alpha$-positions of the pyridinium afforded the $\beta$-aminoporphyrin.

\subsection{Electrochemical functionalization with nucleophile(s) at the meso-position}

\subsubsection{Formation of porphyrin monomers and oligomers}

In 2013, Ruhlmann and co-workers synthesized porphyrin trimers, tetramer and pentamer starting with (poly(4-pyridinyl))porphyrins as nucleophiles and $\mathrm{ZnOEP}^{{ }^{++}}$as the selectively electrogenerated electrophile (Scheme 2B) [37].

In 2014, Devillers, Lucas and coll. presented the versatile redox reactivity of $\mathrm{Ni}$ (II) 10 phenyl-5,15-di-p-tolylporphyrin [11]. Depending on the experimental conditions (solvents, divided/non-divided cell), apart from the above-mentioned dimers, different products were produced such as the meso-chlorinated porphyrin (in presence of $\mathrm{CH}_{2} \mathrm{Cl}_{2}, 78 \%$ yield) and, in presence of triphenylphosphine, the meso-phosphonium porphyrin (72\% yield, Scheme $2 \mathrm{~A}$ ).

In 2015, Devillers, Lucas and co-workers published the efficient electrochemical meso nitration (91\% yield) of the 10-phenyl-5,15-di-p-tolylporphyrin $\mathrm{Mg}(\mathrm{II})$ complex (Scheme 2A, [38]) as earlier reported by Leung and co-workers for ZnOEP [39]. The electrolysis was performed using 3.4 eq. of $\mathrm{NaNO}_{2}$ at a potential corresponding to the generation of the porphyrin cation radical. This nitrated porphyrin was then subjected to an electrochemical reduction on Devarda copper electrode in a $\mathrm{MeOH} / \mathrm{H}_{2} \mathrm{O} / \mathrm{KOH}(0.27 \mathrm{M})$ mixture leading to the free base meso-aminoporphyrin in $80 \%$ yield.

In 2018, the analogue zinc(II) complex was substituted in meso-position with triphenylphosphine using similar conditions as for magnesium(II) porphine [40], i.e. 20 eq. of $\mathrm{PPh}_{3}, 10$ eq. of 2,6-lutidine, at $E_{\text {app }}=0.70 \mathrm{~V} / \mathrm{SCE}$ [41]. Very recently, Ruppert, Weiss and coworkers presented their porphyrin-tweezer target that they wanted to prepare by electrosynthesis starting with 1,3-bis(pyridin-3-ylethynyl)benzene as the dinucleophilic spacer and 10-(4-methoxyphenyl)-5,15-di-p-tolylporphyrin cation radical as the electrophile (Scheme 2A) [42]. 

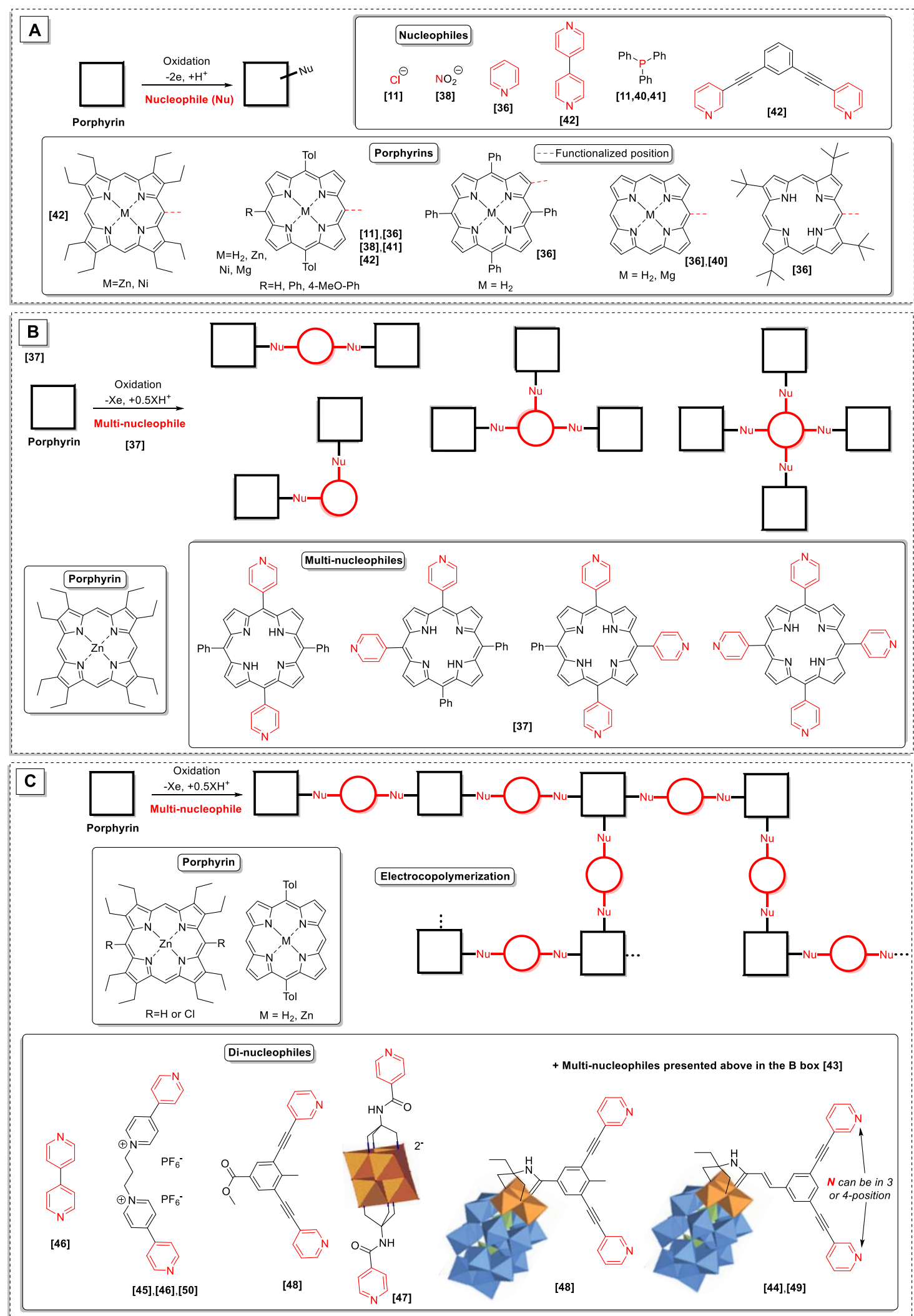

Scheme 2. Functionalization of porphyrin monomers (A, [11,36,38,41,42]); preparation of oligomers (B, [37]); synthesis of copolymers $(\mathrm{C},[43-50])$.

With the MOEP $(\mathrm{M}=\mathrm{Zn}$ and $\mathrm{Ni})$ and 4,4'-bipyridine models, the authors tested the influence

of different parameters (solvent, base, oxidant, reaction time, concentration effect, porphyrin 
complex). But these optimized conditions did not allowed to reach their initial goal since no porphyrin tweezer dimer was isolated. Nevertheless, the substituted porphyrin monomer was prepared in $17 \%$ yield starting with the nickel(II) complex. The authors found that upon oxidation of 10-(4-methoxyphenyl)-5,15-di-p-tolylporphyrin in presence of 1,3-bis(pyridin-3ylethynyl)benzene, the main product of the reaction was the undesired meso,meso dimer resulting from the homocoupling of the generated porphyrin cation radical $[10,11]$.

As aforementioned for the $\beta$-substitution, Devillers and co-workers reported a new regioselective $\mathrm{C}-\mathrm{H}$ amination of free base porphyrins via electrogenerated pyridiniumporphyrins [36]. The reaction was successfully tested on free base porphine, 2,7,12,17-tetratert-butylporphyrin and 5,15-di-p-tolylporphyrin providing first the meso-pyridinium derivatives (61-85\% yield, Scheme $2 \mathrm{~A})$ and then the corresponding amino-porphyrins (81-87\% yield).

\subsubsection{Formation of porphyrin copolymers via dinucleophilic spacers}

In 2012, a direct "easy" electropolymerization method was developed by Ruhlmann by oxidizing $\mathrm{ZnOEP}$ in presence of a mixture of di-, tri- and tetrapyridinyl-porphyrins (Scheme 2C) [43]. These polymers were the first bis-porphyrin copolymers reported in the literature.

In 2013, Hasenknopf, Lacôte, Ruhlmann and co-workers published the synthesis of conjugated Dawson-type polyoxometalate-porphyrin copolymers [44] (Scheme 2C). An important synthetic effort was dedicated to the synthesis of organo-POM monomers bearing two pyridinyl fragments based on the 1,3-bis(pyridin-4(or 3)-ylethynyl)benzene substructure.

Still based on the "easy" electropolymerization method, Bucher, Ruhlmann and coll. reported the electrocopolymerization of $\mathrm{ZnOEP}$ with a flexible dinucleophile (the 1,1"(propane-1,3-diyl)bis(([4,4'-bipyridin]-1-ium)) hexafluorophosphate salt, Scheme 2C) [45,46]. Spectroelectrochemical studies on the material suggested the formation of $\pi$-dimers when the viologen moieties were reduced at the first reduction potential. Varying the POM and the porphyrin nature, the "easy" electrocopolymerization procedure was extended to Lindqvist-type 
polyoxovanadate $\left(\mathrm{TBA}_{2}\left[\mathrm{~V}_{6} \mathrm{O}_{13}\left\{\left(\mathrm{OCH}_{2}\right)_{3} \mathrm{CNHCO}\left(4-\mathrm{C}_{5} \mathrm{H}_{4} \mathrm{~N}\right)\right\}_{2}\right]\right.$ substituted with two pyridinyl groups and $\mathrm{ZnOEP}$ or 5,15-ditolyporphyrin free base [47]. It was shown by EQCM measurements that the electrocopolymerization was much more efficient with $\mathrm{ZnOEP}$ than with the disubstituted 5,15-ditolyporphyrin. The influence of the attachment of a Dawson-type polyoxometalate on the bipyrydinyl spacer was evaluated in another study [48]. The CV analyses of the copolymer material synthesized without preliminary attachment of the POM on the bispyridinyl spacer proved that the porphyrin unit was mainly substituted in meso position by four pyridinium groups whereas the second copolymer which contained the POM only showed a reduction signal that matched with the reduction of two pyridinum fragments. These POM-porphyrin copolymers found applications as photovoltaic electrodes where their photovoltaic performance was investigated by photocurrent transient measurements [49]. In particular the control of the film thickness was of utmost importance to keep a good photocurrent-generation efficiency.

Up to now, all the electrogenerated copolymers have been synthesized by applying a potential that corresponds to the formation of the porphyrin dication. However, in a very recent publication, Ruhlmann and coll. showed that it was possible to generate a copolymer by oxidation of the less hindered zinc(II) 5,15-ditolyporphyrin at its first oxidation step in presence of the flexible 1,1"-(propane-1,3-diyl)bis(([4,4'-bipyridin]-1-ium))hexafluorophosphate bisnucleophile [50]. This new material was compared with the one generated at higher potential (second oxidation of the porphyrin). It was found that the copolymer generated at low potential contained stable isoporphyrin units as proved by ESR measurements.

\subsection{Intramolecular functionalization of porphyrins}

The first electrochemical intramolecular oxidative $\mathrm{C}-\mathrm{C}$ coupling examples were reported by Kadish, Gryko and co-workers with meso-substituted-4,7-dimethoxynaphthalen-1ylporphyrins (Scheme 3A) [51,52]. In these reports, they showed that the formation of the 
dication was necessary to promote the fusion reaction. At this applied potential, the fused product was oxidized to its reactive dication which could lead to further degradation.

In relation with the work of Popp [53] and Yoshida and co-workers [54] which presented the first examples of electrochemical C-N oxidative fusion, Devillers and coll. developed the first chemical and electrochemical oxidative $\mathrm{C}-\mathrm{N}$ fusion of pyridinyl-substituted porphyrins (Scheme 3B) [55]. Interestingly, the C-N fused (di)cationic compounds exhibited higher oxidation potential than the starting unfused porphyrins thanks to the positive charge(s) generated during the $\mathrm{C}-\mathrm{N}$ bond formation. Thus overoxidation of the electrogenerated products was prevented which accounted for the high yields obtained for the fusion reaction.

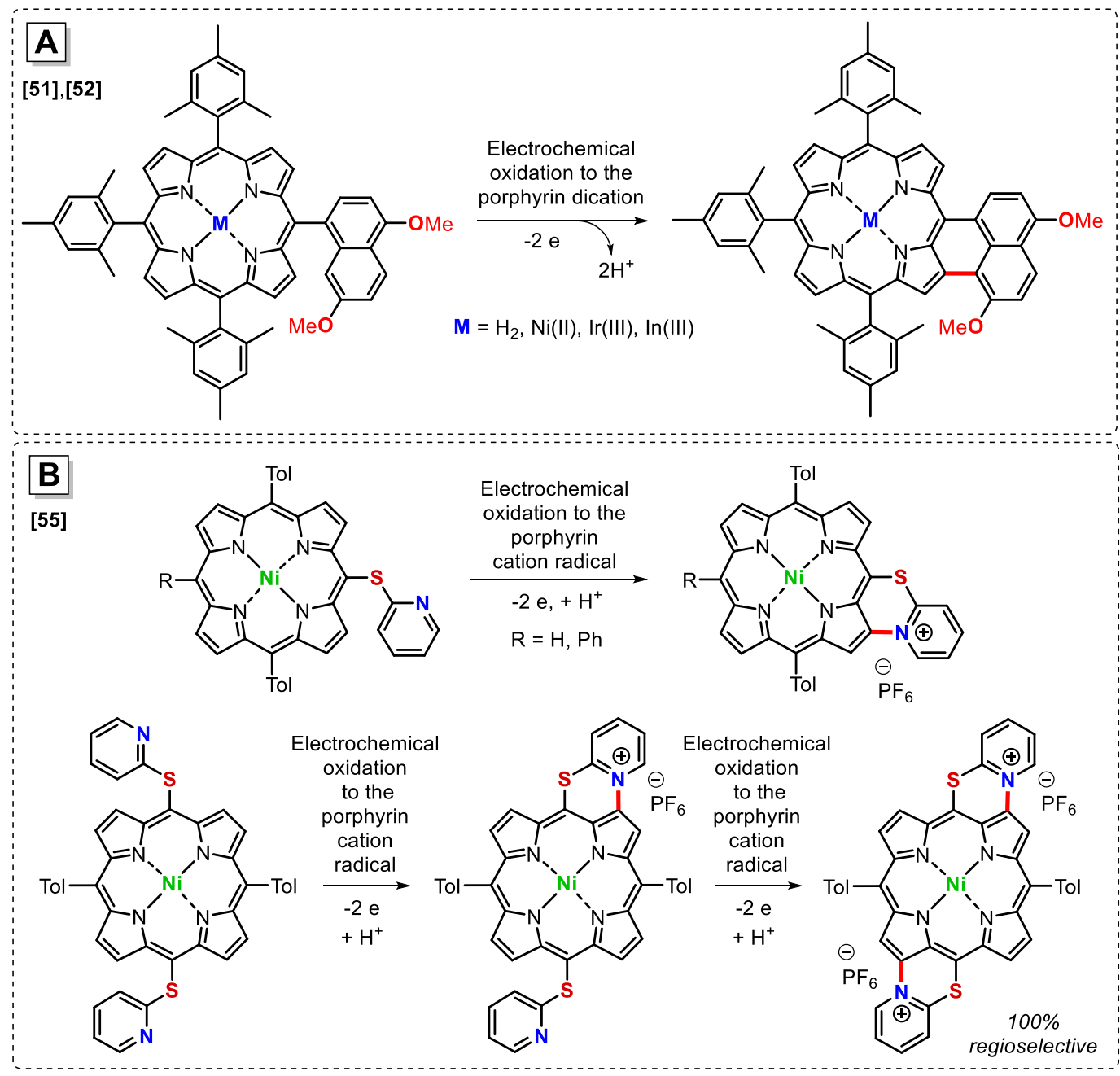

Scheme 3. Intramolecular oxidative C-C (A, [51,52]) and C-N (B, [55]) coupling of porphyrins. 


\section{Electrografting of diazonium-porphyrins}

Electrografting of aryl-diazonium derivatives is currently an active and competitive research field since various materials may be generated by reduction of the diazonium function. Contrary to the electropolymerization method, the electrografting of aryl-diazoniums affords thin films which spans from mono- to multilayers. Porphyrins entered in this research area quite recently.

\subsection{Electrografting of tetraphenylporphyrin-based diazonium}

Despite several recent examples of spontaneous grafting of diazonium-porphyrins onto carbon-based substrates (multi-walled carbon nanotubes [56], reduced graphene oxide [57], graphenides $\mathrm{KC}_{8}$ [58], $\mathrm{GC}$ and carbon cloth $\left.[59,60]\right)$, the first example of electrografted diazonium-porphyrin was reported by Downard, Moutet and co-workers in 2011 (Scheme 4) [61]. The electroreduction of the 4-(10,15,20-triphenylporphyrin-5-yl)benzenediazonium nickel(II) complex led to a relatively stable deposit on gold, glassy carbon (GC), ITO and PPF (pyrolyzed photoresist film) which showed a similar redox behavior than those observed for solute $\mathrm{Ni}(\mathrm{II})$ porphyrins. The surface coverage was compatible with the formation of a monolayer on PPF electrode $\left(\Gamma=2.6 \times 10^{-10} \mathrm{~mol} \mathrm{~cm}^{-2}\right)$.

Mechanism of the electrografting of aryl-diazonium

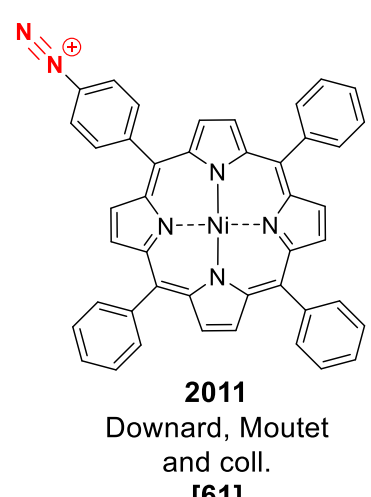

[61]
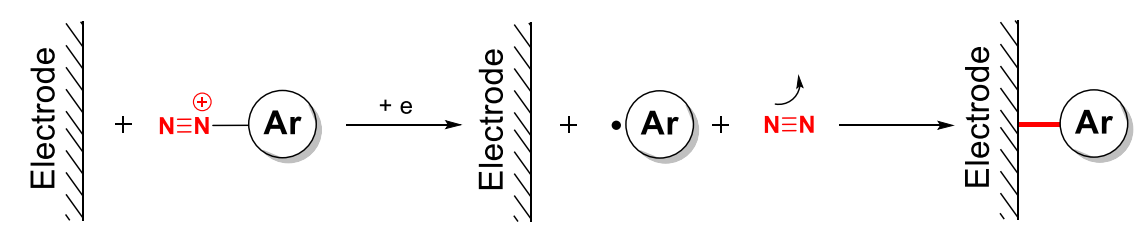

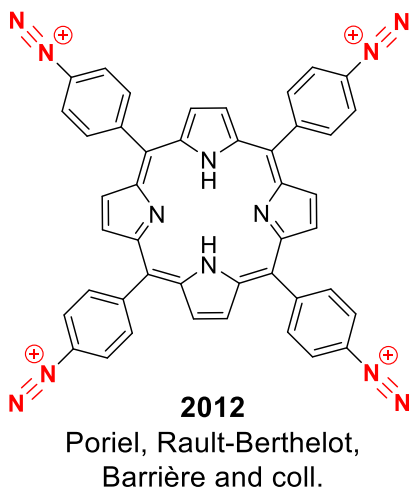

[62]

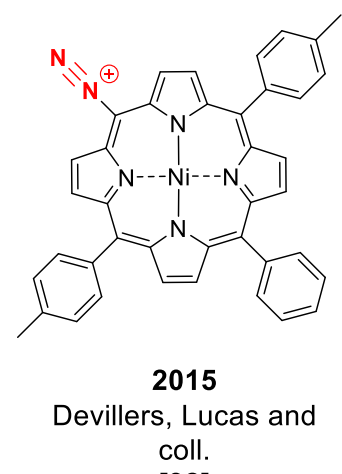

[38]

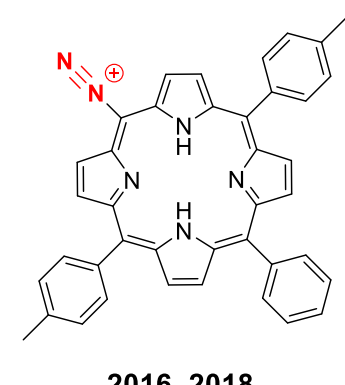

Devillers, Lucas and coll. Limoges, Balland and coll. [64-65]

Scheme 4. Electrografting mechanism of aryl-diazonium (top) and examples of electrografted diazonium porphyrins (bottom, $[38,61,62,64,65])$ 
One year later, Poriel, Rault-Berthelot, Barrière and coll. presented the reductive electrografting of the 4,4',4",4'"-(porphyrin-5,10,15,20-tetrayl)tetrabenzenediazonium derivatives that was generated in situ in aqueous acidic medium from the corresponding aminoporphyrins [62]. Noteworthy, these authors failed to graft the mono-diazoniumsubstituted 4-(10,15,20-triphenylporphyrin-5-yl)benzenediazonium in similar conditions.

Very recently, Celik, Ekinci and coll. described the metalation (Mn(II), Fe(III) and Co(II)) and application of these electrografted tetraphenylporphyrin-based diazoniums towards the electrocatalytic reduction of oxygen [63].

\subsection{Electrografting of meso-diazoniumporphyrins}

In 2015, Devillers, Lucas and co-workers presented the first example of meso-diazoniumporphyrin electrografting (Scheme 4) [38]. The diazonium was generated in situ from the corresponding meso-aminoporphyrin, in organic medium $\left(\mathrm{CH}_{3} \mathrm{CN} 0.1 \mathrm{M} \mathrm{TEABF} 4,2\right.$ eq. $\mathrm{NaNO}_{2}$, $0.5 \mathrm{M}$ TFA, $0.5 \%$ of water). Though counter-intuitive due to the possible steric hindrance generated by the $\beta$-protons surrounding the meso position to be coupled with the electrode, the electrodeposition worked well and the nickel(II) porphyrin-based deposit was characterized by electrochemistry. The surface coverage was calculated to be relatively close to a porphyrin monolayer $\left(\Gamma=5 \times 10^{-10} \mathrm{~mol} \mathrm{~cm}{ }^{-2}\right)$.

One year later, the same group reported an extension of this preliminary work with the electrografting of the corresponding meso-diazonium-porphyrin free base on GC, Pt and ITO [64]. Surprisingly the electrografting was even more efficient and the surface coverage corresponded to multilayers of porphyrins $\left(\Gamma=9-12 \times 10^{-10} \mathrm{~mol} \mathrm{~cm}{ }^{-2}\right)$. To test the robustness of this new free base material, this latter was subjected to a zinc(II) metalation procedure by dipping the modified electrode into a saturated $\mathrm{Zn}(\mathrm{OAc})_{2} \mathrm{CHCl}_{3} / \mathrm{MeOH}$ solution heated at $60^{\circ} \mathrm{C}$. An efficient zinc(II) insertion was demonstrated by electrochemistry and UV-visible absorption spectroscopy and no significant degradation of the porphyrin-based material was 
observed. It was even possible to recover the free base form by dipping the metalated zinc(II) porphyrin film into an $0.2 \mathrm{M} \mathrm{HCl} \mathrm{CH}_{3} \mathrm{CN}$ solution.

In 2018, Limoges, Balland and coll. presented an efficient and homogeneous functionalization of 3D nanostructured transparent ITO electrodes by electrografting of in situ generated free base meso-diazonium porphyrin [65]. The authors showed that the obtained material was homogeneous and that the surface coverage can be easily controlled by the number of grafting scans. The porphyrin-based material was quite resistant to desorption/hydrolysis under organic and aqueous conditions whereas its stability was further demonstrated via zinc(II) metalation experiments. As mentioned by the authors, this robust functionalization of nanostructured transparent metal oxide electrodes opens new perspectives for the development of more stable dye-sensitized or molecular catalyst-functionalized high surface photoelectrodes.

\section{Conclusion}

Recent progress in porphyrin electrochemical functionalization and electro(co)polymerization as well as in electrografting of diazonium-porphyrins have been summarized. In the porphyrin research field, electrochemical functionalization and electrografting are still underdeveloped though they represent a very powerful surrogate to chemical transformations. Indeed, electrochemistry represents a greener alternate technique which generally affords high control and selectivity, low cost and allows for gram scale reactions. Given the recent revival of organic electrochemistry as well as the current development of porphyrin molecules and materials in different essential applications (photovoltaic, sensors, electrocatalysis...), no doubt that further progress in porphyrinoid electrochemical functionalization will be achieved in the next future.

\section{Declaration of interest}

None 


\section{Acknowledgment}

A.K.D.D. and A.B. acknowledges the Ministère de 1'Enseignement Supérieur, de la Recherche et de l'Innovation for a PhD grant. A.K.D.D thanks the Université Alioune Diop de Bambey for funding. C.H.D. thanks the CNRS (Sept. 2015, one year "délégation CNRS”), the Université Bourgogne Franche Comté, the Conseil Régional de Bourgogne through the "Plan d'Actions Régional pour l'Innovation (PARI), the "Fonds Européen de Développement Régional" (FEDER) programs, the ANR (ANR-15-CE29-0018-01) and the French "Investissement d'Avenir" program, project ISITE-BFC (contract ANR-15-IDEX-03) for funding.

\section{References}

Papers of particular interest, published within the period of review, have been highlighted as:

* of special interest

$* *$ of outstanding interest

[1] D. Schaming, A. Giraudeau, L. Ruhlmann, C. Allain, Jian Hao, Y. Xia, R. Fahra, M. Goldmann, Y. Leroux, P. Hapiot, Oxidation of Porphyrins in the Presence of Nucleophiles: From the Synthesis of Multisubstituted Porphyrins to the Electropolymerization of the Macrocycles, in: Electropolymerization, IntechOpen, Dr. Ewa Schab-Balcerzak, Rijeka, 2011: pp. 53-76. https://doi.org/10.5772/29086.

[2] D. Schaming, L. Ruhlmann, Electrosynthesis Processes Based on Oxidative Couplings of Porphyrins for the Formation of Supramolecular Assemblies, in: Handb. Porphyr. Sci., World Scientific Publishing Company, Kadish, Karl M., Smith, Kevin M., Guilard, R., 2014: pp. 127-171. https://doi.org/10.1142/9789814417297_0004.

[3] D. Schaming, L. Ruhlmann, Electrosynthesis of Oligo- and Polyporphyrins Based on Oxidative Coupling of Macrocycles, in: J.H. Zagal, F. Bedioui (Eds.), Electrochem. N4 Macrocycl. Met. Complexes Vol. 2 Biomimesis Electroanal. Electrosynthesis MN4 Met. Complexes, Springer International Publishing, Cham, 2016: pp. 395-432. https://doi.org/10.1007/978-3-319-31332-0_10.

[4] J.L. Röckl, D. Pollok, R. Franke, S.R. Waldvogel, A Decade of Electrochemical Dehydrogenative C,C-Coupling of Aryls, Acc. Chem. Res. 53 (2020) 45-61. https://doi.org/10.1021/acs.accounts.9b00511.

[5] M.D. Kärkäs, Electrochemical strategies for $\mathrm{C}-\mathrm{H}$ functionalization and $\mathrm{C}-\mathrm{N}$ bond formation, Chem. Soc. Rev. 47 (2018) 5786-5865. https://doi.org/10.1039/C7CS00619E.

[6] J. Yoshida, A. Shimizu, R. Hayashi, Electrogenerated Cationic Reactive Intermediates: The Pool Method and Further Advances, Chem. Rev. 118 (2018) 4702-4730. https://doi.org/10.1021/acs.chemrev.7b00475.

[7] M. Yan, Y. Kawamata, P.S. Baran, Synthetic Organic Electrochemical Methods Since 2000: On the Verge of a Renaissance, Chem. Rev. 117 (2017) 13230-13319. https://doi.org/10.1021/acs.chemrev.7b00397.

[8] T. Ogawa, Y. Nishimoto, N. Ono, N. Yoshida, A. Osuka, One-pot electrochemical formation of meso,meso-linked porphyrin arrays, Chem Commun. (1998) 337-338. https://doi.org/10.1039/a707653c. 
[9] T. Ogawa, Y. Nishimoto, N. Yoshida, N. Ono, A. Osuka, Completely Regioselective Synthesis of Directly Linked meso,meso and meso,b Porphyrin Dimers by One-Pot Electrochemical Oxidation of Metalloporphyrins, Angew. Chem. Int. Ed. 38 (1999) 176.

[10]* A.K.D. Dimé, C.H. Devillers, H. Cattey, B. Habermeyer, D. Lucas, Control over the oxidative reactivity of metalloporphyrins. Efficient electrosynthesis of meso,meso-linked zinc porphyrin dimer, Dalton Trans. 41 (2012) 929-936. https://doi.org/10.1039/c1dt11330e.

Efficient electrosynthesis of meso-meso porphyrin dimer. Strong acceleration of the C-C coupling process upon addition of a base.

[11] A.K.D. Dimé, C.H. Devillers, H. Cattey, D. Lucas, Versatile redox reactivity of triarylmeso-substituted Ni(II) porphyrin, Dalton Trans. 43 (2014) 14554-14564. https://doi.org/10.1039/c4dt00221k.

[12]* C.H. Devillers, D. Lucas, A.K.D. Dimé, Y. Rousselin, Y. Mugnier, Exploring the redox reactivity of magnesium porphine. Insight into the origins of electropolymerisation, Dalton Trans. 39 (2010) 2404-2411. https://doi.org/10.1039/b914916c.

Discovery of the oligomerization/electropolymerization ability of magnesium(II) porphine.

[13] C.H. Devillers, P. Fleurat-Lessard, D. Lucas, "Porphine," the Fully Unsubstituted Porphyrin: A Comprehensive Overview, in: K.M. Kadish, K.M. Smith, R. Guilard (Eds.), Handb. Porphyr. Sci., World Scientific Publishing Company, 2016: pp. 75-231. https://doi.org/10.1142/9789813149571_0002.

[14] D.K. Dogutan, M. Ptaszek, J.S. Lindsey, Direct Synthesis of Magnesium Porphine via 1Formyldipyrromethane, J. Org. Chem. $72 \quad$ (2007) 5008-5011. https://doi.org/10.1021/jo070532z.

[15]** M.A. Vorotyntsev, D.V. Konev, C.H. Devillers, I. Bezverkhyy, O. Heintz, Magnesium(II) polyporphine: The first electron-conducting polymer with directly linked unsubstituted porphyrin units obtained by electrooxidation at a very low potential, $\begin{array}{llrrr}\text { Electrochimica } & \text { Actar } & 55 & \text { (2010) }\end{array}$ https://doi.org/10.1016/j.electacta.2010.06.001.

First example of a porphyrin meso-meso electropolymerization onto an electrode surface and characterization of this new material.

[16]* M.A. Vorotyntsev, D.V. Konev, C.H. Devillers, I. Bezverkhyy, O. Heintz, Electroactive polymeric material with condensed structure on the basis of magnesium(II) polyporphine, $\begin{array}{lllll}\text { Electrochimica } & \text { Actar } & 56 & \text { 3436-3442. }\end{array}$ https://doi.org/10.1016/j.electacta.2010.10.039.

Transformation of the semi-conducting meso-meso-linked magnesium(II) porphine polymer into the conducting $\beta, \beta$-meso,meso- $\beta, \beta$-fused polymer.

[17] D.V. Konev, C.H. Devillers, K.V. Lizgina, V.E. Baulin, M.A. Vorotyntsev, Electropolymerization of non-substituted $\mathrm{Mg}(\mathrm{II})$ porphine: Effects of proton acceptor addition, J. Electroanal. Chem. $737 \quad$ (2015) 235-242. https://doi.org/10.1016/j.jelechem.2014.09.018.

[18] D.V. Konev, K.V. Lizgina, O.I. Istakova, V.E. Baulin, I.P. Kalashnikova, C.H. Devillers, M.A. Vorotyntsev, Electropolymerization of magnesium 5,15-di(nmethoxyphenyl)porphine, Russ. J. Electrochem. 52 (2016) 1150-1158. https://doi.org/10.1134/S1023193516120077.

[19] D.V. Konev, C.H. Devillers, K.V. Lizgina, T.S. Zyubina, A.S. Zyubin, L.A. MaiorovaValkova, M.A. Vorotyntsev, Synthesis of new electroactive polymers by ion-exchange replacement of $\mathrm{Mg}$ (II) by $2 \mathrm{H}+$ or $\mathrm{Zn}$ (II) cations inside $\mathrm{Mg}$ (II) polyporphine film, with their subsequent electrochemical transformation to condensed-structure materials, Electrochimica Acta. 122 (2014) 3-10. https://doi.org/10.1016/j.electacta.2013.10.004. 
[20] S.D. Rolle, D.V. Konev, C.H. Devillers, K.V. Lizgina, D. Lucas, C. Stern, F. Herbst, O. Heintz, M.A. Vorotyntsev, Efficient synthesis of a new electroactive polymer of $\mathrm{Co}$ (II) porphine by in-situ replacement of $\mathrm{Mg}$ (II) inside $\mathrm{Mg}$ (II) polyporphine film, Electrochimica Acta. 204 (2016) 276-286. https://doi.org/10.1016/j.electacta.2016.03.039.

[21]* O.I. Istakova, D.V. Konev, A.S. Zyubin, C.H. Devillers, M.A. Vorotyntsev, Electrochemical route to Co(II) polyporphine, J. Solid State Electrochem. 20 (2016) 31893197. https://doi.org/10.1007/s10008-016-3397-y.

First electrochemically assisted metalation of porphyrin material, at room temperature (cobalt(II) insertion).

[22] D.V. Konev, O.I. Istakova, B. Dembinska, M. Skunik-Nuckowska, C.H. Devillers, O. Heintz, P.J. Kulesza, M.A. Vorotyntsev, Electrocatalytic properties of manganese and cobalt polyporphine films toward oxygen reduction reaction, J. Electroanal. Chem. 816 (2018) 83-91. https://doi.org/10.1016/j.jelechem.2018.03.042.

[23] S.D. Rolle, C.H. Devillers, S. Fournier, O. Heintz, H. Gibault, D. Lucas, A glassy carbon electrode modified by a triply-fused-like Co(II) polyporphine and its ability for sulphite oxidation and detection, New J. Chem. 42 (2018) 8180-8189. https://doi.org/10.1039/C7NJ04370H.

[24] A. Tsuda, H. Furuta, A. Osuka, Completely fused diporphyrins and triporphyrin, Angew. Chem. Int. Ed. 39 (2000) 2549.

[25] A. Tsuda, A. Osuka, Fully Conjugated Porphyrin Tapes with Electronic Absorption Bands That Reach into Infrared, Science. 293 (2001) 79.

[26] A. Tsuda, H. Furuta, A. Osuka, Syntheses, Structural Characterizations, and Optical and Electrochemical Properties of Directly Fused Diporphyrins, J. Am. Chem. Soc. 123 (2001) 10304.

[27] L. El Kahef, M. El Meray, M. Gross, A. Giraudeau, Electrochemical synthesis of $\beta$ pyridinium zinc tetraphenylporphyrin, J. Chem. Soc. Chem. Commun. (1986) 621-622. https://doi.org/10.1039/C39860000621.

[28] L. El Kahef, M. Gross, A. Giraudeau, $\beta$-Substitutions on meso-tetraphenylporphyrin by direct electrochemical oxidation in the presence of nucleophiles, J. Chem. Soc. Chem. Commun. (1989) 963-963. https://doi.org/10.1039/C39890000963.

[29] A. Giraudeau, L. El Kahef, $\beta$-Substitution de la méso-tétraphénylporphyrine de zinc par voie électrochimique, Can J Chem. 69 (1991) 1161-1165. https://doi.org/10.1139/v91-173.

[30] A. Brisach-Wittmeyer, S. Lobstein, M. Gross, A. Giraudeau, Electrochemical reduction of 1-(meso-tetraphenylporphyrin)-pyridinium cations, J. Electroanal. Chem. 576 (2005) 129.

[31] A. Giraudeau, L. Ruhlmann, L.E. Kahef, M. Gross, Electrosynthesis and Characterization of Symmetrical and Unsymmetrical Linear Porphyrin Dimers and Their Precursor Monomers, J Am Chem Soc. 118 (1996) 2969-79. https://doi.org/10.1021/ja9523956.

[32] L. Ruhlmann, A. Giraudeau, One-pot electrochemical generation of a porphyrin dimer with a bis(diphenylphosphonium)acetylene bridge, Chem. Commun. (1996) 2007-2008. https://doi.org/10.1039/CC9960002007.

[33] L. Ruhlmann, A. Giraudeau, A first series of dimeric porphyrins electrochemically linked with diphosphonium bridges, Eur J Inorg Chem. (2001) 659-668. https://doi.org/10.1002/1099-0682(200103)2001:3<659::AID-EJIC659>3.0.CO;2-B.

[34] L. Ruhlmann, M. Gross, A. Giraudeau, Bisporphyrins with bischlorin features obtained by direct anodic coupling of porphyrins, Chem - Eur J. 9 (2003) 5085-5096. https://doi.org/10.1002/chem.200304924.

[35] T. Morofuji, A. Shimizu, J. Yoshida, Electrochemical C-H Amination: Synthesis of Aromatic Primary Amines via N-Arylpyridinium Ions, J. Am. Chem. Soc. 135 (2013) 5000-5003. https://doi.org/10.1021/ja402083e. 
[36]** A. Bousfiha, A.K.D. Dimé, A. Mankou-Makaya, J. Echaubard, M. Berthelot, H. Cattey, A. Romieu, J. Roger, C.H. Devillers, Regioselective C-H amination of free base porphyrins via electrogenerated pyridinium-porphyrins and stabilization of easily oxidized amino-porphyrins by protonation, Chem. Commun. 56 (2020) 884-887. https://doi.org/10.1039/C9CC07351E.

First example of electrochemical $\mathrm{C}-\mathrm{H}$ amination of porphyrins.

[37] D. Schaming, Y. Xia, R. Thouvenot, L. Ruhlmann, An Original Electrochemical Pathway for the Synthesis of Porphyrin Oligomers, Chem. Eur. J. 19 (2013) 1712-1719. https://doi.org/10.1002/chem.201203271.

[38]** S. Hebié, A.K.D. Dimé, C.H. Devillers, D. Lucas, Electrochemistry as an Attractive and Effective Tool for Synthesis and Immobilization of Porphyrins on Electrode Surface, Chem. Eur. J. 21 (2015) 8281-8289. https://doi.org/10.1002/chem.201404314.

First example of meso-diazonium-porphyrin electrografting.

[39] G.Z. Wu, H.K. Leung, Meso-substitution reaction of zinc octaethylporphyrin via anodic oxidation, Chin. Chem. Lett. 1 (1990) 1-4.

[40] C.H. Devillers, A.K.D. Dimé, H. Cattey, D. Lucas, Electrochemical mesofunctionalization of magnesium(II) porphine, Chem. Commun. 47 (2011) 1893-1895. https://doi.org/10.1039/c0cc04309e.

[41] A.K.D. Dimé, H. Cattey, D. Lucas, C.H. Devillers, Electrosynthesis and X-ray Crystallographic Structure of $\mathrm{Zn}(\mathrm{II})$ meso-Triaryltriphenylphosphonium Porphyrin and Structural Comparison with $\mathrm{Mg}(\mathrm{II})$ meso-Triphenylphosphonium Porphine, Eur. J. Inorg. Chem. 2018 (2018) 4834-4841. https://doi.org/10.1002/ejic.201801142.

[42] R. Lamare, L. Ruhlmann, R. Ruppert, J. Weiss, Case studies of the radical cation reactivity in meso-aryl and octaethyl porphyrins, J. Porphyr. Phthalocyanines. 24 (2019) 860-868. https://doi.org/10.1142/S1088424619501980.

[43]* Y. Xia, D. Schaming, R. Farha, M. Goldmann, L. Ruhlmann, Bis-porphyrin copolymers covalently linked by pyridinium spacers obtained by electropolymerization from $\beta$ octaethylporphyrins and pyridyl-substituted porphyrins, New J. Chem. 36 (2012) 588-596. First bis-porphyrin copolymer example.

[44] I. Azcarate, I. Ahmed, R. Farha, M. Goldmann, X. Wang, H. Xu, B. Hasenknopf, E. Lacôte, L. Ruhlmann, Synthesis and characterization of conjugated Dawson-type polyoxometalate-porphyrin copolymers, Dalton Trans. 42 (2013) 12688-12698. https://doi.org/10.1039/C3DT50850A.

[45] Z. Huo, J.-P. Gisselbrecht, R. Farha, M. Goldmann, E. Saint-Aman, C. Bucher, L. Ruhlmann, Alternating electro-copolymerization of zinc- $\beta$-octaethylporphyrin with a flexible bipyridinium, Electrochem. Electroact. Mater. 122 (2014) 108-117. https://doi.org/10.1016/j.electacta.2013.10.058.

[46] Z. Huo, A. Bonnefont, Y. Liang, R. Farha, M. Goldmann, E. Saint-Aman, H. Xu, C. Bucher, L. Ruhlmann, Photovoltaic properties of supramolecular assemblies obtained by incorporation of Preysler's type polyoxometalate in a polycationic copolymer of porphyrin, Electrochimica Acta. 274 (2018) 177-191. https://doi.org/10.1016/j.electacta.2018.04.088.

[47] Z. Huo, D. Zang, S. Yang, R. Farha, M. Goldmann, B. Hasenknopf, H. Xu, L. Ruhlmann, Synthesis and characterization of Lindqvist-type polyoxometalate-porphyrin copolymers, Electrochimica Acta. 179 (2015) 326-335. https://doi.org/10.1016/j.electacta.2015.03.178.

[48] Z. Huo, I. Azcarate, R. Farha, M. Goldmann, H. Xu, B. Hasenknopf, E. Lacôte, L. Ruhlmann, Copolymeric films obtained by electropolymerization of porphyrins and dipyridyl-spacers including Dawson-type polyoxometalates, J. Solid State Electrochem. 19 (2015) 2611-2621. https://doi.org/10.1007/s10008-015-2828-5.

[49] I. Azcarate, Z. Huo, R. Farha, M. Goldmann, H. Xu, B. Hasenknopf, E. Lacôte, L. Ruhlmann, Generation of Photocurrent by Visible-Light Irradiation of Conjugated Dawson 
Polyoxophosphovanadotungstate-Porphyrin Copolymers, Chem. - Eur. J. 21 (2015) 82718280. https://doi.org/10.1002/chem.201406178.

[50] M. Boudiaf, Y. Liang, R. Lamare, J. Weiss, H. Ibrahim, M. Goldmann, E. Bentouhami, V. Badets, S. Choua, N. Le Breton, A. Bonnefont, L. Ruhlmann, Stable isoporphyrin copolymer: Electrochemical mechanism and behavior and photovoltaic properties, Electrochimica Acta. 309 (2019) 432-449. https://doi.org/10.1016/j.electacta.2019.04.050.

[51]** P. Chen, Y. Fang, K.M. Kadish, J.P. Lewtak, D. Koszelewski, A. Janiga, D.T. Gryko, Electrochemically Driven Intramolecular Oxidative Aromatic Coupling as a Pathway toward $\pi$-Extended Porphyrins, Inorg. Chem. $52 \quad$ (2013) 9532-9538. https://doi.org/10.1021/ic401214e.

First example of electrochemical oxidative intramolecular C-C coupling of a porphyrin with its peripheral naphtalene-based substituent.

[52] Y. Fang, D. Koszelewski, K.M. Kadish, D.T. Gryko, Facile electrosynthesis of $\pi$ extended porphyrins, Chem. Commun. 50 (2014) 8864-8867. https://doi.org/10.1039/C4CC02759K.

[53] G. Popp, Nucleophilic substitutions initiated by electrochemical oxidation. I. Intramolecular nucleophilic substitutions, J. Org. Chem. 37 (1972) 3058-3062. https://doi.org/10.1021/jo00985a003.

[54] T. Morofuji, A. Shimizu, J. Yoshida, Electrochemical Intramolecular C-H Amination: Synthesis of Benzoxazoles and Benzothiazoles, Chem. - Eur. J. 21 (2015) 3211-3214. https://doi.org/10.1002/chem.201406398.

[55]** M. Berthelot, G. Hoffmann, A. Bousfiha, J. Echaubard, J. Roger, H. Cattey, A. Romieu, D. Lucas, P. Fleurat-Lessard, C.H. Devillers, Oxidative C-N fusion of pyridinylsubstituted porphyrins, Chem. Commun. 54 (2018) 5414-5417. https://doi.org/10.1039/C8CC01375F.

First example of an electrochemical intramolecular oxidative $\mathrm{C}-\mathrm{N}$ coupling between a porphyrin and a pyridine-based substituent.

[56] Z.-B. Liu, Z. Guo, X.-L. Zhang, J.-Y. Zheng, J.-G. Tian, Increased optical nonlinearities of multi-walled carbon nanotubes covalently functionalized with porphyrin, Carbon. 51 (2013) 419-426. https://doi.org/10.1016/j.carbon.2012.09.005.

[57] A. Wang, W. Yu, Z. Huang, F. Zhou, J. Song, Y. Song, L. Long, M.P. Cifuentes, M.G. Humphrey, L. Zhang, J. Shao, C. Zhang, Covalent functionalization of reduced graphene oxide with porphyrin by means of diazonium chemistry for nonlinear optical performance, Sci. Rep. 6 (2016) 23325. https://doi.org/10.1038/srep23325.

[58] H.-L. Hou, D. Dasler, F. Hauke, A. Hirsch, Reductive Functionalization of Graphenides With Nickel(II) Porphyrin Diazonium Compounds, Phys. Status Solidi RRL - Rapid Res. Lett. 11 (2017) 1700306. https://doi.org/10.1002/pssr.201700306.

[59] A.N. Marianov, Y. Jiang, Effect of Manganese Porphyrin Covalent Immobilization on Electrocatalytic Water Oxidation and Oxygen Reduction Reactions, ACS Sustain. Chem. Eng. 7 (2019) 3838-3848. https://doi.org/10.1021/acssuschemeng.8b04735.

[60] A.N. Marianov, Y. Jiang, Covalent ligation of Co molecular catalyst to carbon cloth for efficient electroreduction of CO2 in water, Appl. Catal. B Environ. 244 (2019) 881-888. https://doi.org/10.1016/j.apcatb.2018.11.084.

[61]** A.J. Gross, C. Bucher, L. Coche-Guerente, P. Labbé, A.J. Downard, J.-C. Moutet, Nickel (II) tetraphenylporphyrin modified surfaces via electrografting of an aryldiazonium salt, Electrochem. Commun. 13 (2011) 1236-1239. https://doi.org/10.1016/j.elecom.2011.08.035.

First electrografting of a porphyrin via electroreduction of its phenyl-diazonium substituent.

[62] M. Picot, I. Nicolas, C. Poriel, J. Rault-Berthelot, F. Barrière, On the nature of the electrode surface modification by cathodic reduction of tetraarylporphyrin diazonium salts 
in aqueous media, Electrochem. Commun. 20 (2012) 167-170. https://doi.org/10.1016/j.elecom.2012.04.020.

[63] Z. Kudas, U. Atmaca, T. Saruhan, M. Celik, D. Ekinci, Electrocatalytic Reduction of Oxygen at Glassy Carbon Electrodes Coated with Diazonium-derived Porphyrin/Metalloporphyrin Films, Electroanalysis. 32 (2020) 1379-1390. https://doi.org/10.1002/elan.201900707.

[64] S. Hebié, C.H. Devillers, S. Fournier, D. Lucas, Direct Grafting of Free-Base mesoTriarylporphyrins on Electrode Materials through Diazonium Reduction: Reversible Zinc(II) Metallation of the Resulting Materials, ChemElectroChem. 3 (2016) 45-50. https://doi.org/10.1002/celc.201500433.

[65] Y.-S. Kim, S. Fournier, S. Lau-Truong, P. Decorse, C.H. Devillers, D. Lucas, K.D. Harris, B. Limoges, V. Balland, Introducing Molecular Functionalities within High Surface Area Nanostructured ITO Electrodes through Diazonium Electrografting, ChemElectroChem. 5 (2018) 1625-1630. https://doi.org/10.1002/celc.201800418. 